\title{
Hubungan Penggunaan Helm dengan Derajat Cedera Kepala Akibat Kecelakaan Lalu Lintas pada Pengendara Sepeda Motor di RSUP Dr. M. Djamil Padang Tahun 2016-2017
}

\author{
Sharon Serafim Bosawer', Rizki Rahmadian', Zelly Dia Rofinda ${ }^{3}$ \\ ${ }^{1}$ Program Studi Profesi Dokter Fakultas Kedokteran Universitas Andalas, Padang \\ ${ }^{2}$ Bagian Ortopedi Fakultas Kedokteran Unversitas Andalas/RSUP Dr. M. Djamil Padang \\ ${ }^{3}$ Bagian Patologi Klinik Fakultas Kedokteran Universitas Andalas/RSUP Dr. M. Djamil Padang
}

\begin{abstract}
Latar Belakang. Kecelakaan lalu lintas merupakan masalah kesehatan masyarakat di dunia, dan penyebab utama kasus cedera kepala dengan kontributor utama pengendara sepeda motor. Penggunaan helm pada pengendara sepeda motor dapat mengurangi resiko terjadi cedera kepala, dengan cara mengurangi gaya tumbukan yang mengenai kepala.

Objektif. Tujuan dari penelitian ini adalah untuk mengetahui hubungan penggunaan helm dengan derajat cedera kepala akibat kecelakaan lalu lintas pada pengendara sepeda motor di RSUP Dr. M. Djamil Padang pada tahun 2016-2017.

Metode. Penelitian ini merupakan penelitian analitik dengan desain cross sectional. Teknik pengambilan sampel yang digunakan adalah teknik probability sampling menggunakan random sampling, dengan 93 sampel. Data diperoleh dari data rekam medis pasien cedera kepla yang mengalami kecelakaan lalu lintas menggunakan sepeda motor dan dirawat di RSUP Dr. M. Djamil Padang pada tahun 2016 sampai 2017. Analisis data menggunakan uji chi square.
\end{abstract}

Hasil. Hasil penelitian menunjukkan laki-laki $(67,7 \%)$, tidak menggunakan helm (72\%) dan jenis cedera kepala terbanyak adalah cedera kepala berat (50,5\%). Terdapat hubungan yang bermakna antara penggunaan helm dengan derajat cedera kepala akibat kecelakaan lalu lintas pada pengendara sepeda motor $(p=0,002)$.

Kesimpulan. Terdapat hubungan antara penggunaan helm pada pengendara sepeda motor dengan derajat cedera kepala akibat kecelakaan lalu lintas.

Kata kunci: cedera kepala, helm, kecelakaan lalu lintas

Background. Traffic accidents are a public health problem in the world, and the main cause of head injury cases with the main contributor is motorcycle riders. The use of helmets on motorcycle riders can reduce the risk of head injury, by reducing the impact force on the head.
Objective. The objective of this study is to determine the relationship between the use of helmet and the degree of head injury due to a traffic accidents on motorcyclists at RSUP Dr. M. Djamil Padang in 2016-2017.

Methods. This study was an analytic study with cross sectional design.The sample was conducted by probability sampling technique using random sampling with 93 samples. Data were obtained from medical records of head injury patients who suffered traffic accidents using motorcycle and treated at RSUP Dr. M. Djamil Padang in 2016-2017. Data were analyzed using chi square test.

Results. The results showed man $(67,7 \%)$, did not use helmet (72\%), and most types of head injuries are severe head injuries $150,5 \%$. There was a significant relationship between the use of helmets with the degree of head injury due to traffic accidents on motorcycle riders $(p=0,002)$.

Conclusion. There was a relationship between the use of helmets on motorcycle riders with the degree of head injury due to traffic accidents.

Keyword : head injury, helmet, traffic acidents,

Apa yang sudah diketahui tentang topik ini?

Helm memiliki beberapa lapisan yang berperan untuk melindungi kepala dari benturan saat kecelakaan lalu lintas

\section{Apa yang ditambahkan pada studi ini?}

Sebagian besar yang mengalami cedera kepala berat adalah pengendara sepeda motor yang tidak menggunakan helm saat kecelakaan lalu lintas

\section{CORRESPONDING AUTHOR}

Phone: +6281344934664

E-mail: serafim1807@yahoo.com 


\section{Pendahuluan}

Kecelakaan lalu lintas merupakan masalah kesehatan masyarakat di seluruh negara, khususnya di negara berkembang. ${ }^{1}$ Cedera kepala penyebab dari kecelakaan lalu lintas menempati urutuan ke sembilan pada disability adjusted life year (DALY) dan diperkirakan akan meningkat menjadi peringkat ke tiga di tahun 2020, sedangkan di negara berkembang menempati urutan ke dua. ${ }^{1,2}$ Kecelakaan lalu lintas juga merupakan penyebab utama kematian secara global. World Health Organization (WHO) menyatakan bahwa sekitar 1,25 juta orang di dunia meninggal setiap tahun akibat kecelakaan lalu lintas. ${ }^{2}$

Menurut World Health Organization (WHO), pada tahun 2013 terjadi lebih dari seperempat kematian akibat kecelakaan lalu lintas di Asia Tenggara, yaitu sebanyak 316.000 orang tewas dalam kecelakaan lalu lintas. ${ }^{3}$ Kejadian kematian akibat kecelakaan lalu lintas di Indonesia sebanyak 17,0 per 100.000 penduduk, sebanyak $70 \%$ korban kecelakaan lalu lintas adalah pengendara sepeda motor. ${ }^{3}$ Pada tahun 2017 di Sumatera Barat terdapat kecelakaan lalu lintas sebanyak 2.781 kejadian dan jumlah kejadian di Kota Padang sebanyak 536, dengan 42 korban meninggal, 259 luka berat dan 492 luka ringan. ${ }^{4}$

Kecelakaan lalu lintas dapat mengakibatkan berbagai trauma dan cedera kepala adalah yang paling banyak terjadi. Cedera kepala merupakan permasalahan utama dalam kesehatan masyarakat serta penyebab utama kematian dan cedera di seluruh dunia. ${ }^{5}$ Berdasarkan Riskesdas tahun 2018 proporsi cedera kepala secara nasional adalah 11,9\% dimana sebanyak 72,7\% penyebab cedera kepala adalah kecelakaan lalu lintas dengan mengendarai sepeda motor dan $19,2 \%$ sebagai penumpang sepeda motor. ${ }^{6}$ Pada data awal yang diperoleh dari Instalasi Rekam Medik di RSUP Dr. M. Djamil Padang kasus cedera kepala mengalami peningkatan selama tiga tahun terakhir yakni tahun 2015 sebanyak 198 kasus, pada tahun 2016 menjadi 633 kasus dan pada tahun 2017 terdapat 628 kasus.

Kontributor utama dari kecelakaan yang mengakibatkan cedera kepala serius dan fatal adalah sepeda motor, khususnya pada pengendara sepeda motor yang tidak menggunakan helm, yaitu sebanyak 85\%,6,7 Menurut World Health Organization (WHO) helm dapat mengurangi risiko keparahan dari cedera sebanyak $72 \%$, dan mengurangi kemungkinan kematian akibat cedera sampai $39 \%^{8}$

Pada penelitian yang dilakukan oleh Junaid A. Bhatti, et al. di Pakistan pada 1 Januari 2007 hingga 31 Desember 2013, didapatkan 109.201 total pengendara sepeda motor yang terluka, dimana sebanyak $5,6 \%$ pasien yang memakai helm dan yang tidak memakai helm sebesar 94,4\%. Pasien yang mengalami cedera kepala didapatkan 37.439 (34,3\%), dengan insiden terbanyak terjadi pada pasien yang tidak menggunakan helm yaitu $36.797 \quad(98,3 \%)$. Kesimpulan dari penelitian ini adalah helm efektif mengurangi kemungkinan kematian dan cedera kepala serius pada pengendara sepeda motor di Pakistan. $^{9}$

Berdasarkan penelitian yang dilakukan Mulyadi dan Gresty Maria Masi di rumah sakit Bhayangkara Manado dan di rumah sakit umum pusat Prof. Dr. R. D. Kandou Manado pada tanggal 19 November 2016 hingga 13 Desember 2016 didapatkan 137 (100\%) pasien cedera kepala, sebanyak 107 (78,1\%) tidak menggunakan helm dengan insiden cedera kepala sedang berjumlah $54(39,4 \%)$ dan cedera kepala berat sebanyak 8 $(5,8 \%) .{ }^{10}$

Menurut penelitian yang dilakukan Anna. E. Forbes, et al. di London pada tahun 2017 insiden cedera kepala lebih rendah pada pengendara yang menggunakan helm. Insiden kecelakaan sepeda motor yang didapatkan dari penelitian ini yaitu 323, sebanyak 129 pasien mengalami cedera kepala dengan $54 \%$ diantaranya tidak menggunakan helm dan hanya $21 \%$ pasien yang menggunakan helm. ${ }^{11}$

Penelitian yang dilakukan Maximiana Cristina de Souza Maliska, et al. di California Selatan menunjukkan jika pengendara sepeda motor yang menggunakan helm saat terjadinya kecelakaan maka risiko kematian bisa berkurang sebanyak $42 \%$, sedangkan pada pengendara tanpa helm 
mempunyai risiko cedera kepala dan kematian sebanyak 3,1 kali lipat. ${ }^{12}$

Penelitian yang dilakukan Kiki Rahmadan, et al. pada tahun 2013 di RSUD Zainoel Abidin dari 52 pasien cedera kepala, sebanyak 31 pasien tidak menggunakan helm dan presentasi kasus terbanyak adalah cedera kepala sedang yaitu 20 pasien (64,5\%). Pada penelitian ini terdapat korelasi yang signifikan antara pemakaian helm denfan derajata cedera kepala $(\mathrm{p}<0,05) .{ }^{13}$

Berdasarkan penjelasan dan data di atas, maka penulis terdorong untuk mengetahui hubungan penggunaan helm dengan derajat cedera kepala akibat kecelakaan lalu lintas pada pengendara sepeda motor yang dirawat di rumah sakit umum pusat Dr. M. Djamil Padang pada tahun 2016 sampai 2017.

\section{Metode}

Penelitian ini merupakan penelitian analitik dengan pendekatan cross sectional. Teknik pengambilan sampel yang digunakan adalah probability sampling dengan cara random sampling. Populasi untuk penelitian ini adalah semua pengendara sepeda motor yang mengalami cedera kepala akibat kecelakaan lalu lintas pada tahun 2016 sampai 2017. Sampel penelitian berjumlah 93 sampel yang dipilih dari seluruh populasi yang sesuai dengan kriteria inklusi hingga jumlah yang dibutuhkan terpenuhi. Kriteria inklusi yaitu pasien cedera kepala akibat kecelakaan lalu lintas pada pengendara sepeda motor. Kriteria eksklusi yaitu pasien yang data rekam medik tidak lengkap dan tidak dapat dihubungi untuk konfirmasi penggunaan helm saat terjadi kecelakaan lalu lintas.

Data yang dikumpulkan adalah data sekunder berupa derajat cedera kepala yang diperoleh dari catatan rekam medis. Selanjutnya peneliti menghubungi pasien untuk meminta konfirmasi penggunaan helm saat terjadi kecelakaan lalu lintas.

Analisis data yang dilakukan adalah analisis univariat dan bivariat. Analisis univariat digunakan untuk mendeskripsikan karakteristik setiap variabel penelitan antara lain usia, jenis kelamin, penggunaan helm dan derajat cedera kepala, dengan menggunakan tabel distribusi frekuensi. Analisis bivariat digunakan untuk menguji hipotesis antar dua variabel, yang akan diketahui hubungannya yaitu penggunaan helm dengan derajat cedera kepala. Uji yang digunakan adalah uji chi square, variabel dianggap memiliki hubungan yang bermakna atau signifikan apabila nilai $\mathrm{p}<0,05$.

\section{Hasil}

Penelitian ini dilakukan di bagian rekam medis RSUP Dr. M. Djamil Padang. Data awal yang diperoleh peneliti dari tahun 2016 sampai 2017 berjumlah 1.261 rekam medis. Dari jumalh tersebut didapatkan 93 yang menjadi sampel penelitian.

Tabel 1. Distribusi frekuensi karakteristik pasien cedera kepala akibat kecelakaan lalu lintas di RSUP Dr. M. Djamil Padang berdasarkan usia.

\begin{tabular}{lll}
\hline Usia & $\mathbf{f}$ & $\mathbf{\%}$ \\
\hline 15-20 tahun & 43 & 46,2 \\
21-30 tahun & 12 & 12,9 \\
31-40 tahun & 12 & 12,9 \\
41-50 tahun & 12 & 12,9 \\
$>$ 50 tahun & 14 & $15,1 \%$ \\
\hline Total & 93 & $100 \%$ \\
\hline
\end{tabular}

Berdasarkan tabel 1 diperoleh data responden terbanyak adalah usia 15-20 tahun yaitu sebanyak 43 orang (46,2\%), sedangkan pada usia lebih dari 50 tahun terdapat 14 orang $(15,1 \%)$, sebagian kecil dari responden berusia 21-30 tahun yaitu 12 $(12,9 \%)$, tidak ada perbedaannya dengan responden usia 31-40 tahun yaitu 12 (12,9\%) dan juga responden berusia 41-50 tahun sebanyak 12 $(12,9 \%)$

Tabel 2. Distribusi frekuensi karakteristik pasien cedera kepala akibat kecelakaan lalu lintas di RSUP Dr. M. Djamil Padang berdasarkan jenis kelamin.

\begin{tabular}{lll}
\hline Jenis Kelamin & $\mathbf{f}$ & $\mathbf{\%}$ \\
\hline Laki-laki & 63 & 67,7 \\
Perempuan & 30 & 32,3 \\
\hline Total & 93 & $100 \%$ \\
\hline
\end{tabular}

Berdasarkan tabel 5.2 diperoleh data bahwa responden terbanyak pada penelitian ini adalah laki-laki yaitu sebanyak 63 orang $(67,7 \%)$ dan sebagian kecil responden perempuan yaitu 30 orang $(32,3 \%)$. 
Tabel 3. Distribusi frekuensi penggunaan helm pada pasien cedera kepala akibat kecelakaan lalu lintas di RSUP Dr. M. Djamil Padang.

\begin{tabular}{lll}
\hline Penggunaan Helm & $\mathrm{f}$ & $\%$ \\
\hline Ya & 26 & 28 \\
Tidak & 67 & 72 \\
\hline Total & 93 & $100 \%$ \\
\hline
\end{tabular}

Berdasarkan tabel 3, diperoleh sebagian besar responden tidak menggunakkan helm yaitu sebanyak 67 orang (72\%) dan sebagian responden yang menggunakan helm yakni 26 orang (28\%).

Tabel 4. Distribusi frekuensi derajat cedera kepala pada pasien cedera kepala akibat kecelakaan lalu lintas di RSUP Dr. M. Djamil Padang.

\begin{tabular}{lll}
\hline Cedera Kepala & F & \% \\
\hline Cedera kepala ringan & 33 & 35,5 \\
Cedera kepala sedang & 13 & 14 \\
Cedera kepala berat & 47 & 50,5 \\
\hline Total & 93 & $100 \%$ \\
\hline
\end{tabular}

Berdasarkan tabel 4, diperoleh data bahwa responden yang mengalami cedera kepala berat dengan jumlah terbanyak yakni 47 orang $(50,5 \%)$, sebagian kecil dari responden yakni 33 orang $(35,5 \%)$ mengalami cedera kepala ringan dan 13 orang $(14 \%)$ mengalami cedera kepala sedang.

Tabel 5. Hubungan penggunaan helm dengan derajat cedera kepala

\begin{tabular}{lclll}
\hline \multirow{5}{*}{ Penggunaan } & Cedera & Cedera & Cedera & \\
Helm & Kepala & Kepala & Kepala & $P$ \\
& Ringan & Sedang & Berat & Value \\
& $\%$ & $\%$ & $\%$ & \\
Ya & 61,5 & 15,4 & 23,1 & \\
Tidak & 25,4 & 13,4 & 61,2 & 0,002 \\
Total & 35,5 & 14 & 50,5 & \\
\hline
\end{tabular}

Berdasarkan hasil analisis dengan menggunakan uji chi square dengan software SPSS menunjukkan sebagian besar responden yang tidak menggunakan helm mengalami cedera kepala berat, dengan nilai $\mathrm{p}=0,002(\mathrm{p}<0,05)$. Hasil tersebut dapat disimpulkan secara statistik bahwa terdapat hubungan yang bermakna (signifikan) antara penggunaan helm dengan derajat cedera kepala akibat kecelakaan lalu lintas pada pengendara sepeda motor di RSUP Dr. M. Djamil Padang tahun 2016-2017.

\section{Pembahasan}

Karakteristik sampel penelitian berdasarkan usia didapatkan frekuensi terbanyak pada usia muda yang merupakan usia produktif 15-20 tahun yaitu 43 responden $(46,2 \%)$. Hal ini tidak jauh berbeda dengan penelitian di Aceh pada tahun 2013 yang memperoleh frekuensi tertinggi sebanyak 24 responden (46,2\%) pada usia 15-20 tahun. ${ }^{13}$ Kecelakaan lalu lintas yang mengakibatkan cedera kepala sebagian besar terjadi pada usia produktif karena pada usia ini seseorang memiliki fase kehidupan yang lebih aktif secara fisik dan sosial. ${ }^{14}$ Terbanyak kedua didapatkan pada usia $>50$ tahun ini disebabkan karena penurunan kemampuan dan ketrampilan berkendara. ${ }^{15}$

Karakteristik berdasarkan jenis kelamin didapatkan laki-laki lebih banyak dibandingkan perempuan. Hal ini sesuai dengan distribusi jenis kelamin berdasarkan Riskesdas tahun 2018 yaitu laki- laki lebih tinggi mengalami cedera kepala $2,9 \%$ dibanding perempuan $1,6 \%{ }^{6} \quad$ Pada penelitian yang dilakukan di Aceh, frekuensi jenis kelamin laki-laki tertinggi yaitu sebanyak 41 responden (78,8\%) sedangkan perempuan sebanyak 11 responden $(21,2 \%){ }^{13}$ Alasan lakilaki lebih banyak yaitu karena ada peran hormon testosteron pada laki-laki yang jauh lebih tinggi dibandingkan pada perempuan, sehingga menyebabkan laki-laki lebih agresif dan berperilaku dengan cara yang beresiko dibandingkan perempuan yaitu dengan melanggar aturan penggunaan helm. ${ }^{14,16}$

Penelitian ini menunjukan sebagian besar tidak menggunakan helm. Hasil penelitian ini sesuai dengan penelitian yang dilakukan di rumah sakit Bhayangkara Manado dan di RSUP Prof. Dr. R. D. Kandou Manado pada tahun 2016 diperoleh pasien cedera kepala 137, 30 responden $(21,9 \%)$ menggunakan helm dan 107 responden (78,1\%) yang tidak menggunakan helm. ${ }^{9}$

Pada penelitian ini menurut responden yang tidak menggunakan helm karena tidak adanya sanksi yang tegas dari pihak berwajib untuk pengendara sepeda motor yang tidak menggunakan helm, sehingga sebagian besar dari 
responden merasa helm hanya atribut dalam berkendara yang tidak wajib untuk digunakan. Jarak tempuh yang tidak jauh juga menjadi alasan bagi sebagian responden untuk tidak menggunakan helm.

Pada penelitian ini derajat cedera kepala berat didapatkan tertinggi dibandingkan cedera kepala ringan dan sedang, cedera kepala berat memiliki nilai Glasgow coma scale (GCS) kurang dari 9 yaitu 3-8, hal ini dikaitkan dengan penurunan klinis dan hasil yang buruk. ${ }^{17}$

Hal ini tidak sesuai dengan penelitian yang dilakukan Sikandar Ali, et al. pada tahun 2018 yaitu dari 1.600 kasus, didapatkan pasien cedera kepala ringan 1.088 kasus (68\%) lebih tinggi dari cedera kepala sedang dan cedera kepala berat. ${ }^{18}$ Penelitian yang dilakukan Kiki Rahmadan, et al. pada tahun 2013 di RSUD Zaionel Abidin terdapat perbedaan juga dengan hasil penelitian ini yaitu dari 52 pasien, frekuensi tertinggi adalah cedera kepala sedang sebanyak 20 pasien $(64,5 \%){ }^{13}$

Perbedaan yang terjadi karena pada penelitian ini masih terdapat kelainan intrakranial pada responden yang menggunakan helm dengan tidak tepat sehingga mengakibatkan helm terlepas saat kecelakaan, helm yang terlepas saat kecelakaan punya peluang lima kali lebih besar untuk mengalami cedera kepala dan empat kali lebih besar mengalami cedera kepala berat. ${ }^{19}$ Helm yang digunakan dengan tepat dapat mengurangi resiko cedera kepala dengan cara mengurangi pengaruh gaya tumbukan yang mengenai kepala. ${ }^{20}$

Berdasarakan Hasil uji statistic menunjukkan bahwa terdapat hubungan yang bermakna antara penggunaan helm dengan derajat cedera kepala, ini disimpulkan karena nilai signifikan atau $p$ kurang dari 0,05. Hasil penelitian ini sesuai dengan penelitian yang dilakukan Kiki Rahmadan, et al. di RSUD Zainoel Abidin pada tahun 2013 terdapat korelasi yang signifikan antara pemakaian helm dengan derajat cedera kepala $(\mathrm{p}<0,05)$.

Menurut penelitian yang dilakukan Maxima Cristina de Souza Maliska, et al. di California Selatan, jika pengendara sepeda motor menggunakan helm saat terjadi kecelakaan, maka risiko cedera kepala dan kematian bisa berkurang $42 \%$, sebaliknya jika tidak menggunakan helm maka risiko cedera kepala dan kematian menjadi 3,1 kali lipat. ${ }^{11}$

\section{Simpulan}

Terdapat hubungan yang bermakna antara penggunaan helm dengan derajat cedera kepala akibat kecelakaan lalu lintas pada pengendara sepeda motor di rumah sakit umum pusat Dr. M. Djamil Padang.

\section{Ucapan Terima Kasih}

Penulis mengucapkan terimakasih kepada semua pihak yang telah memberikan bimbingan, arahan, bantuan, dan motivasi kepada penulis sehingga penulis dapat menyelesaikan penelitian ini.

\section{Daftar Pustaka}

1. Toroyan T. Global status report safety 2015. Geneva : World Health Organization ; 2015. p. vii-x

2. Toroyan T. Global status report safety 2009. Geneva : World Health Organization ; 2009. p.vi

3. Chowdhury S, Santikan C. Road safety in the southeast asia region 2015. New Delhi : World Health Organization ; 2016. p. 7-8

4. Badan Pusat Statistik (2017). Data kecelakaan lalu lintas yang terjadi di Provinsi Sumatera Barat. (https ://solokkota.bps.go.id/statictable/2018/09/27/518/ data-kecelakaan-lalu-lintas-yang-terjadi-di-provinsisumatera-barat-2017.html). Diakses Januari 2019

5. Peden M, Scurfield R, Sleet DA, Mohan D, Hyder AA, Jarawan E, Mathers C. World report on road traffic injury prevention. Geneva : World Health Organization ; 2004.p. x-xi

6. Kementrian Kesehatan Republik Indonesia. Hasil utama Riskesda 2018. Jakarta : Badan Penelitian dan Pengembangan Kesehatan ; 2018.

7. Faul M, Xu L, Wald MM, Coronado VG. Traumatic brain injury in the United States: emergency department visits, hospitalizations, and deaths. Atlanta : National center for injury prevention and control; 2010. p. 5-21

8. WHO. Helmets : a road safety manual for decisionmakers and practitioners. Geneva : World Health Organization; 2006. p. 3-20

9. Bhatti JA, Razzak JA, Khan UR, Jooma R. Helmets and traffic injury outcomes: finding from a setting lacking legislation on ptoper wearing and quality assessment. Cogent Med. 2018; 5: 1434031

10. Mulyadi, Masi GM. Hubungan penggunaan helm dengan derajat cedera kepala akibat kecelakaan lalu lintas darat di RSUP. Prof. Dr. R. D Kandou Manado dan RS. Bhayangkara Manado. Jurnal Keperawatan. 2017; 5: 1

11. Forbes AE, Weissmann JS, Menassa DA, Wilson HM. Head injury patterns in helmeted and non- helmeted cyclists admitted to a London major trauma centre with serious head injury. PLoS Med. 2017; 12: 9

12. Maliska MCS, Borba M, Asprino L, Moraes MD, Willian $\mathrm{R}$, et al. Oral and maxillofacial surgery- Helmet and maxillofacial trauma: a 10-year retrospective study. Braz J Oral Sci. 2012; 11(2): 125-29.

13. Rahmadhani K. Hubungan pemakaian helm dengan derajat cedera kepala pada pengendara sepeda motor(Skripsi). Banda Aceh: Universitas Syah Kuala; 2013 
14. Chelly H, Bahloul M, Ammar R, Dhouib A, Mahfoudh K Ben, Boudawara MZ, et al. Clinical characteristics and prognosis of traumatic head injury following road traffic accidents admitted in ICU "analysis of 694 cases". Eur J Trauma Emerg Surg. 2019; 45(2): p. 24553.

15. Institute of advanced motories (2010). Older driverssafe or unsafe. IAM driving road safety. https://www.iamroadsmart.com/docs/defaultsource/research-reports/iam-olderdrivers2010.pdf?sfvrsn=95dffa50_2. Diakses Maret 2020.

16. Pawlowski B, Atwal R, Dunbar RIM. Sex differences in everyday risk taking behavior in humans. Evolutionary Psychology. 2008;6(1):p.29-42

17. Teasdale G, Allen D, Brennan P. Forty years on: updating the Glasgow Coma Scale. Nursing time. 2014; 110(42):12-16

18. Ali S, Mohsin M, Bajwa I, Nasir H, Butt RM. Six month's analysis of head injury due to motor bike accidents in Punjab institute of neurosciences (PINS), lahore. Pak J of Neurol Surg. 2019;23(1):21

19. Ramli R, Oxley J. Motorcycle helmet fixation status is more crucial than helmet type in providing protection to the head. Injury. 2016; 47(11):p.2442-49

20. Badan Standarisasi Nasional. Penerapan standar wajib SNI 1811-2007 helm pengendara kendaraan bermotor roda dua. Jakarta. 2007 